\title{
Economic Development of City Marketing on the Basis of Its Historical and Cultural Heritage
}

\author{
${ }^{1}$ Lilyana A. Sosunova, ${ }^{2}$ Natalia V. Astafieva, ${ }^{3}$ Natalia I. Voitkevich, ${ }^{4}$ Arkady P. Plotnikov \\ *5 Milana A. Ibragimova \\ ${ }^{1}$ Professor, Head of the Department of Marketing, Advertising and Logistics, Samara State University of \\ Economics, Samara, Russian Federation \\ ${ }^{2}$ Professor of the Department of Labor Economics and Production Complexes, Yuri Gagarin State Technical \\ University of Saratov, Russian Federation \\ ${ }^{3}$ Professor, Department of Commerce, Service and Tourism, Samara, Russian Federation \\ ${ }^{4}$ Professor, Department of Economic Security and Innovation Management, Yuri Gagarin State Technical University \\ of Saratov, Russian Federation \\ ${ }^{5}$ Post-graduate student of the Department of Marketing, Logistics and Advertising, Samara State University of \\ Economics, Samara, Russian Federation \\ Email:kafedra-kl@yandex.ru,nvasta@mail.ru,vki63@list.ru,arcd1@yandex.ru, ${ }^{*}$ milana5.92@mail.ru
}

Received: $09^{\text {th }}$ May 2018, Accepted: $25^{\text {th }}$ May 2018, Published:30 ${ }^{\text {th }}$ June $_{2018}$

\begin{abstract}
In the current globalization of the market, the vast majority of the society has changed its worldview under the current conditions for development of socioeconomic relations. It became clear that a new economic era is coming, and the post-industrial transition contains powerful challenges. Cities began to lose their traditional production functions, and there was a need to create their new competitive advantages in the changed conditions. One of the modern directions that allow solving this problem is "city marketing". The article is aimed at researching the essence of city marketing on the basis of studying its historical and cultural heritage, as well as determining how historical and cultural heritage affects the city's economic development. The leading approach to this research is the interpretative approach to the development and use of historical and cultural heritage in the city's marketing activity. The main results of the article are: definition of the role of city marketing while creating a positive image of the city; perspective directions for the development of the city's marketing activity, the use of which is necessary for the development of marketing strategy; directions for the development of cities' potential in the Volga Federal District of the Russian Federation (using the example of Samara and Saratov) while disclosing their unique features. The materials of the article can be useful in forming a marketing strategy for the city development, as well as improving the efficiency of the management system of municipalities.
\end{abstract}

Keywords: Investment Attractiveness, Historical and Cultural Heritage, City Marketing, Economic potential

\section{Introduction}

The field of culture, which was previously regarded as an intangible sphere, developing according to its own specific laws, has recently become the object of both scientific study and economic interest. Culture is increasingly seen as a development engine and a means of supporting economic growth. The sphere of culture can create sources of income through tourism, crafts, historical and cultural heritage, contributing to the region's sustainable development and the country as a whole. In developed countries, the field of culture is now of great economic importance in terms of increasing employment and distribution of income generated, and for developing countries, the sphere of culture can be considered as an area for potential breakthrough and improvement of living standards.

To improve the urban environment, it is necessary to create favorable conditions for attracting investments and developing tourism. To this end, in our opinion, one of the most important components, like the city identity, should be used, so that when you are visiting the city, you get a feeling of its uniqueness and peculiarities, that is, a special "sense of the city". At the heart of the motivation for visiting urban places and attractions should be laid the need to get acquainted with the unique urban environment, due to the history and traditions of the place.

In European countries, historical and cultural heritage objects, as well as cultural events taking place in the city, are necessary conditions for the development and successful functioning of the city. Many cities in Europe have made houses in the style of "Art Nouveau", and they are proud of them since they are unique. People overcome considerable distances to admire unusual houses, mansions in the "modern" 
style in Vienna, Glasgow, Paris, and Brussels. Consequently, the heritage of these cities is preserved and popularizes not itself, but the whole city and the country as a whole. There is an increasing understanding that it is necessary to make a "performance" of the city, to represent the city as a "showcase" for broadcasting cultural events and presentations, as well as for attracting investments. A certain special atmosphere of the city, its "idea" attracts tourists. At the same time, the income to the budget from tourists visiting the city is enormous. Without historical and cultural heritage, the modern life of the city and the prospects for its development are unthinkable. Heritage in many ways shapes the mentality of inhabitants of this territory, maintains humanistic values, emphasizes the cultural status of the city and creates its positive image. Cultural heritage has the same significance as natural resources, deposits of gas, oil, etc. It is included in many social processes and is a source of spiritual enrichment. The presence of cultural heritage contributes to the harmonious development of a wide range of activities of the whole society.

Mobilization of the economic resource of cultural heritage is the basis for urban regeneration. The preservation of the historical urban environment ensures the investment attractiveness of the city and its real commercial value. This should be expressed not only in the immediate economic impact and growth of employment in various fields of activity, but also in a wide range of indirect benefits that will become the property of the entire urban community (income from heritage management, restoration, tourism and its infrastructure).

Thus, within the framework of modern cultural policy, historical and cultural heritage is realized not only as an important fact of the past, but also as an active of the present, as a specific economic resource for the development of individual businesses, cities and entire regions. Each city can be compared with a product whose main content, interesting for the outside world and space - guests, tourists, etc., is the spiritual and intellectual atmosphere in which city residents live and support it with their efforts.

Initially, all industrial cities were significantly similar to each other, so municipal authorities began to look for individual characteristics of their cities (Figure 1).

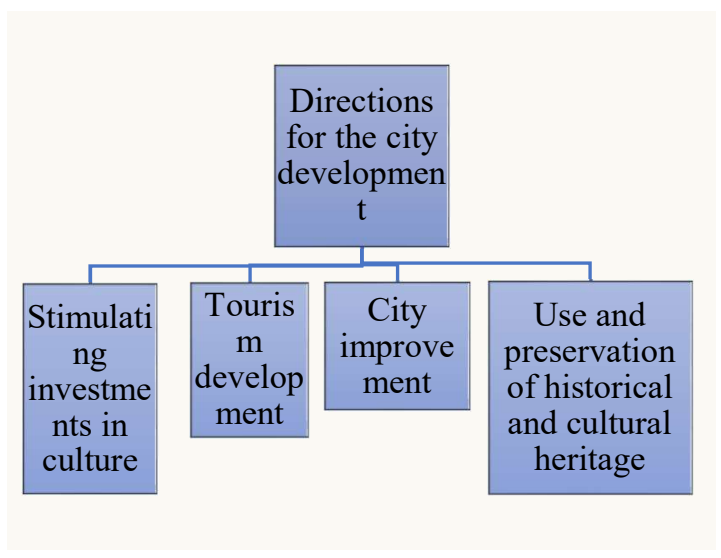

Fig. 1 -Directions for the City Development Source: Compiled by the Authors.

The promotion of the city is now becoming one of the main components of the strategic plan for the city development by the municipal administrative apparatus. To implement the strategy in terms of creating the city image when perceived by its potential guests and residents, long-term and purposeful actions of both city and business authorities and all its residents are needed.

Russia has a fantastic historical and cultural heritage. Historical buildings are restored, identified and entered a single register, but historical and cultural heritage at the end of the restoration of buildings, as a rule, is not proper applied. And again after a certain time the building begins to wreck.

Historical and cultural heritage can be preserved only through the adaptation of the object, when the monument gains a new functionality and is developing. It is very important to note here that you need to find a connection with the consumer. However, at present, the need to preserve and use historical and cultural heritage is most often considered by developers and managers as a factor capable to reduce the economic value of the object. This approach does not take into account the economic potential inherent in historical and cultural heritage. Preservation and proper use of historical and cultural heritage objects can bring a positive economic effect, and the presence of historical and cultural heritage can be regarded as an additional asset of the city and its competitive advantage. 
Thus, the restoration of cultural and historical objects, the creation of new cultural attractions, investment in modern cultural industries are solutions that will enable the authorities of many cities to make real and successful steps towards regenerating the urban environment and developing the city's economic potential by attracting tourists and investors (Galkin, 2005) [1]. Successful implementation of such projects has gradually received the name - city marketing.

\section{Brief Literature Review}

The works of such scientists as D. Delafons (1997) [2], W. Morris (1973) [3], D. Rypkema (2005) [4], D. Highfield (1991) [5], and D. Harvey (2001) [6] are devoted to the research of problems of preservation and use of historical and cultural heritage and evaluation of its influence on the development of countries and regions.

Theoretical and methodological issues of strategic management and development of marketing were considered in the works of such foreign scientists as $\mathrm{P}$. Doyl' (2001) [7], P. Drucker (2007) [8], Kotler Dzhayn \& Meysinsi (2003) [9], M. Porter \& Kramer (2006) [10] and others.

It should also be noted that in the late 1990s and early 2000 s, international organizations carried out research aimed at studying the impact of culture on sustainable development of the city, including the achievement of long-term economic growth. In 1995, the report of the UNESCO Commission on Culture and Development "Our Cultural Diversity" was published; in 1999 - the World Bank report "Culture and sustainable development: a guide to action"; in 2005 - OECD report "Culture and municipal development", etc. In the conducted researches the high role of the state in culture was shown.

Among domestic researchers who made a significant contribution to the development of economic fundamentals in the sphere of culture, it is necessary to single out the following works: T. B. Abankina (2003) [11], E. L. Ignat'yeva (2013) [12], E.P. Kostina (2012) [13], V. Yu. Muzychuk (2013) [14], A. Ya. Rubinshtein (2013) [15], B. L. Rudnik (2015) [16], L.I. Yakobson (2015) [17].

In modern research, scientists and specialists in the field of culture and economy of the city considered a wide range of issues related to the development of the urban environment, preservation and use of historical and cultural heritage and assessment of its impact on the development of countries and regions. However, in our opinion, insufficient attention is paid to considering the issues of proper use of cultural heritage objects, solving the problem of combining emotions and rationality in establishing the effective contact between the object and the visitor. Cultural heritage objects require special attention and study at the moment, since their role in the process of forming the city image, raising the cultural level of the population, developing the socio-cultural component of the quality of life and enhancing the city's investment attractiveness remains unclear.

It should be noted that various approaches to understanding the perception of cultural heritage objects have been developed now. In the present study, the authors consider the theory of the interpretational approach to the development and use of historical and cultural heritage in the city's marketing activity in more detail, which allows disclosing the meaning of the historical and cultural heritage object, and establishing contact between the object and the visitor.

\section{Stating the Purpose}

The purpose of this research is to develop theoretical and methodological foundations for city marketing and to offer promising areas for increasing the effectiveness of the city's marketing activity, the use of which is necessary to implement the marketing strategy and develop directions for the growth of the city's economic potential based on its unique features. To achieve the goal of the research it is necessary to solve various tasks, the most important of which is the consideration of historical and cultural heritage as a specific economic resource for city marketing, contributing to the development of a separate business, and the city and the country as a whole.

This research is urgent and timely, as it is aimed at solving the most important task that is essential for the development of the city's marketing activity and can increase its economic potential in the current economic conditions. The research is aimed at the development of theoretical and practical provisions, the totality of which can be qualified as the development of city marketing on the basis of its unique features and historical and cultural heritage, which has a significant socio-economic significance for raising culture, economic growth and increasing the revenue budget of the city, region and country as a whole. The results of the research are also of great importance in developing a marketing strategy and determining the directions for the development of the city's economic potential.

Recommendations and proposals formulated in the article have theoretical and practical significance, and can be used by official representatives of municipalities and regional authorities in justifying management decisions to improve the city's marketing activity and determine promising areas for the city's economic development.

Outlining the Structure of the Paper

This research, devoted to the development of the city's marketing activity and the enhancement of its 
economic potential on the basis of its unique features and historical and cultural heritage, has a structure that allows disclosing its content in a logical sequence.

The research has the following structure:

- Annotation;

1. Introduction;

2. Description of the theoretical and methodological base of the research;

3. Research results;

4. Discussion of previously achieved and obtained scientific results;

5. Conclusion;

- Recommendations;

- Literature review.

\section{Methodological Framework}

In carrying out this research, general scientific principles and methods of cognition are used: empirical-theoretical (observation, measurement, description) and logical-theoretical (comparison, analysis and synthesis, deduction, modeling) research methods; system, process, and interpretation approaches; program-target and structural-functional methods; statistical methods of processing economic data.

As an analytical basis, statistical data of socioeconomic and marketing activities in the cities of the Volga Federal District of the Russian Federation (using the example of Samara, Saratov) are used as an analytical basis, both from open official sources and materials collected personally by the authors.

\section{Stages of the Research}

The initial stage of the research includes a detailed study of the history of the city's development and identification of its existing historical and cultural heritage objects.

At the second stage, a SWOT analysis is carried out, which allows showing the city's condition in the use of historical and cultural heritage objects, reflecting the strengths and weaknesses of the city, as well as obstacles and opportunities for achieving the set goals in the sphere of city marketing. At this stage, it is also necessary to carry out a comparative analysis of theoretical and practical developments in the field under research.

At the third stage, the definition of promising areas for the development of the city's marketing activity is being made, the use of which is necessary to develop a marketing strategy and justify the development of the city's economic potential.

\section{Results}

At the beginning of the research, the authors determine the opportunities for the economic development of city marketing and the rethinking of its historical and cultural heritage as a cultural and economic phenomenon, for example, in the cities of the Volga Federal District of the Russian Federation - Samara, Saratov.

The cities of Samara and Saratov are major cultural, economic and educational centers of the Volga region, which are included in the twenty largest cities of Russia. They are located on the right bank of the Volga river, at a distance of $442 \mathrm{~km}$ from each other. Each of these cities, like many other cities in the Volga Federal District of the Russian Federation, is characterized by its sights that are historical and cultural heritage objects, has its own unique history of creation and development, but at the same time, having similarities in common with other Russian cities, they have their own specific features that distinguish them from other Russian cities. The authors consider the unique features of these cities in more detail.

Nowadays Samara is one of the largest cities of Russia with its rich culture and glorious history, which goes back centuries. The life of the city is inextricably linked with the great Volga river. The center of modern Samara is an ensemble of historical buildings and monuments of architecture. In the heart of the city there are numerous theaters, museums, monuments, parks, Gothic churches and Orthodox churches. Nowadays, Samara has a large number of historical and cultural monuments (Figure 2)

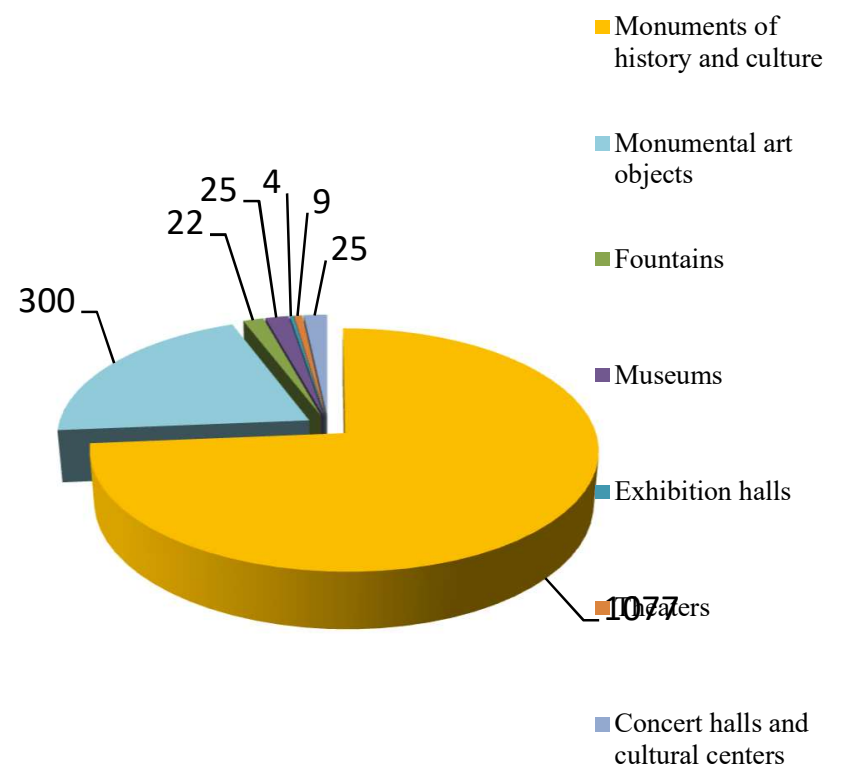

Fig. 2 -Tourist objects in Samara, units Source: compiled by the authors

As it can be seen in Figure 2, almost $74 \%$ of all tourist objects are monuments of history and culture. Currently, the following areas have high potential: 
1) History and culture: architecture, literature, art;

2) Soviet era in the 1950-1960's.

The richness of historical and cultural heritage of the Soviet era - this is strength of Samara. This is the building of the elevator on Khlebnaya Square, the Maslennikov kitchen-plant is the only building in the world in the form of a sickle and hammer, etc. Here one can emphasize the halo of a "closed" city, which was an industrial base for the Soviet space program.

However, after analyzing the social and economic situation in Samara, it can be concluded that, having high potential and unique opportunities, as well as adequate resources, the city administration does not use them enough for the development and prosperity of the city. In the presence of a significant number of monuments of architecture and culture, the further development of Samara should, in our opinion, take into account existing historical and cultural heritage. It is necessary to look at this city in a new way, to see its huge potential and to make efforts for its active growth, which will contribute to the development of the Middle Volga and Russia as a whole. Certainly, the FIFA World Cup, which will be held in Samara in 2018, provides a unique opportunity to demonstrate the uniqueness of this city both to Russian and foreign tourists, as well as the international community.

Another analyzed city in the Volga Federal District of the Russian Federation is Saratov, which at present is a multifunctional center with numerous industrial, cultural, educational institutions. Among the regions of Russia, the city of Saratov and the Saratov region stand out as a kind of historical, cultural and architectural heritage. Classicism and rational modernism, established in the region at the turn of the XIX - XX centuries, became the "golden age" of Saratov architecture. Despite the rapid change of styles, the town-planning structure of the cities in the region has retained its logic. In the region there are also a number of localities connected with German culture and history.

The city of Saratov is a large industrial and cultural center of Russia. The industry of the city is represented by enterprises of machine-building, electrotechnical, energy, chemical, oil refining, light and food industries. There are dozens of higher education institutions, research and design institutes and branches. Saratov is proud of many monuments of history and architecture, old manors, museums, theaters and other attractions, built from the end of the XVII to the beginning of the XX century (Figure 3).

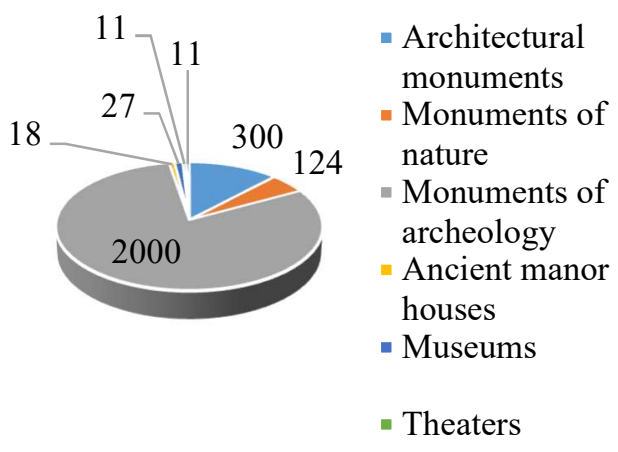

Fig. 3- Tourist objects in Saratov, units

Source: compiled by the authors

The most famous sights of the city of Saratov are: the Opera and Ballet Theater, the Drama Theater, the Saratov State Conservatory named after L.V. Sobinova, the circus named after Nikitin brothers, Philharmonic, Saratov Art Museum named after A. N. Radishcheva, the museum-estate and the monument to N.G. Chernyshevsky, Troitsky Cathedral in the Museum Square, the Temple of "Assuage my sorrows", a road bridge across the Volga, connecting the city. Saratov and Engels, which is the visiting card of the city, the memorial complex "Victory Park" on Sokolova Hill, which includes: the museum of military equipment, the monument to Saratov warriors "Cranes", the museum "National Village", as well as the monument on the site of the first landing in the world by cosmonaut Yu. A. Gagarin and other attractions. Recently, the city of Saratov has been enriched with new monuments: the monument to the Saratov Governor - P.A. Stolypin, the monument to St. Cyril and Methodius, the monument of the Saratov accordion, etc.

A good preservation of historical buildings in the Saratov region is due to the fact that the new construction of the Soviet period was conducted outside historical centers of cities. In the central regions, local transformations were carried out, and in the new regions, the architecture of constructivism developed, which became Russia's main contribution to the world architecture of the 20th century. Today, the Soviet neoclassic is also recognized. In a good condition there are monuments of industrial architecture, which includes a powerful layer of cultural heritage. The value of cultural heritage in the Saratov region is its authenticity, universality and universal significance of its heritage (On the Strategy for the Development of the Cultural Heritage of the Saratov Region, 2008) [18].

The old buildings in the center of the city are gradually restored, but some are being destroyed, and those of the buildings that are occupied by commercial 
organizations are often unregulated, despite the conservation status of these monuments. The threats and risks of destruction of heritage sites are also related to natural aging. Lack of proper protection of buildings and structures from weather conditions, man-caused stress on soils and structures, aggressive environmental impact (gas contamination, acid rain, adverse environmental conditions, etc.) create a cumulative effect. The regional Duma periodically discusses the need for restructuring the central part of the city of Saratov, but it is not profitable for investors to build up the historic center of the city.

Thus, after analyzing the socio-economic situation in Saratov, it should be also noted that, having its high potential, rich historical and cultural heritage, unique opportunities and corresponding resources, the city administration does not sufficiently use them to develop and improve the city and improve the quality of life of its inhabitants.

The urgent issue for both Samara and Saratov is the issue of prospects for urban development. The understanding of historical and cultural heritage as a cultural and economic phenomenon is still at the initial stage. At the same time, it should be noted that rethinking historical and cultural heritage and transforming it from a traditional to the interpretative approach is a new and important step in the city's comprehensive development, preserving its existing heritage, creating a positive image and increasing its economic potential.

Prerequisites for increasing the investment attractiveness of the city, creating a positive image and improving its business reputation, and therefore, increasing the valuation of the city are shown in Figure 4.

\begin{tabular}{|c|c|}
\hline \multicolumn{2}{|c|}{ Marketing (Advertising, PR) } \\
\hline \multicolumn{2}{|c|}{$\downarrow$} \\
\hline \multicolumn{2}{|c|}{ Creation of a "unique trade offer" of } \\
the city \\
\hline \multicolumn{2}{|c|}{$\downarrow$} \\
\hline \multicolumn{2}{|c|}{$\downarrow$} \\
\hline $\begin{array}{c}\text { In material } \\
\text { objects }\end{array}$ & $\begin{array}{c}\text { in objects of } \\
\text { intellectual property }\end{array}$ \\
\hline $\begin{array}{c}\text { Cultural heritage } \\
\text { objects }\end{array}$ & $\begin{array}{c}\text { Literary, artistic } \\
\text { and scientific works }\end{array}$ \\
\hline $\begin{array}{c}\text { Recreational } \\
\text { objects }\end{array}$ & $\begin{array}{l}\text { The trade mark } \\
\text { (brand) of the city } \\
\text { (increase in its } \\
\text { Tourist objects } \\
\text { memorability, } \\
\text { recognizability, scale, } \\
\text { aesthetic perception) }\end{array}$ \\
\hline
\end{tabular}

\begin{tabular}{|c|c|}
\hline \begin{tabular}{|l|}
\multicolumn{2}{|c|}{ Infrastructure } \\
objects (transport, \\
social, information, \\
etc.)
\end{tabular} & \begin{tabular}{|l|}
\multicolumn{1}{c|}{ Industrial } \\
designs, inventions in \\
all fields of activity
\end{tabular} \\
\hline \multicolumn{2}{|c|}{$\downarrow \downarrow \downarrow$} \\
\hline \multicolumn{2}{|c|}{$\begin{array}{l}\text { Enhancing of the city's } \\
\text { competitiveness }\end{array}$} \\
\hline & $\downarrow$ \\
\hline \multicolumn{2}{|c|}{ Increase in aggregate demand } \\
\hline & $\downarrow$ \\
\hline \multicolumn{2}{|c|}{$\begin{array}{l}\text { Growth in the purchasing power and } \\
\text { well-being of the city's population }\end{array}$} \\
\hline & $\downarrow$ \\
\hline \multicolumn{2}{|c|}{$\begin{array}{c}\text { Increase of the city's investment } \\
\text { attractiveness }\end{array}$} \\
\hline & \\
\hline \multirow{2}{*}{\multicolumn{2}{|c|}{$\begin{array}{l}\text { Development of the city's positive } \\
\text { image and its business reputation }\end{array}$}} \\
\hline & \\
\hline Inc & ra \\
\hline
\end{tabular}

Fig. 4 - Influence of city marketing on increasing its investment attractiveness

Source: compiled by the authors

In the framework of the research, a full, comprehensive study of the city potential is needed. Having analyzed the data about Samara, Saratov, it will be possible to present a plan of actions and recommendations necessary for further development and increase investment attractiveness of these cities in the future.

Conducting a SWOT-analysis allows showing a full picture of the cities in the use of historical and cultural heritage objects, reflecting their strengths and weaknesses, as well as obstacles and opportunities for achieving the goals.

In accordance with the traditional approach to the strategic planning process, the study analyzed the strengths and weaknesses of Samara, Saratov in the use of historical and cultural heritage objects in order to improve the image of the cities (Table 1).

Tab. 1: Strengths and weaknesses of Samara, Saratov in the use

of historical and cultural heritage objects

\begin{tabular}{|c|c|}
\hline Strengths & Weaknesses \\
\hline $\begin{array}{c}\text { Location on the } \\
\text { Volga river }\end{array}$ & $\begin{array}{c}\text { Insufficiently } \\
\text { developed infrastructure } \\
\text { of the city }\end{array}$ \\
\hline $\begin{array}{c}\text { Uniqueness of } \\
\text { natural landscapes }\end{array}$ & $\begin{array}{c}\text { Insufficient } \\
\text { information about the }\end{array}$ \\
\hline
\end{tabular}


Helix Vol. 8(4): 3470- 3480

\begin{tabular}{|c|c|}
\hline & $\begin{array}{l}\text { tourist product among } \\
\text { partners }\end{array}$ \\
\hline $\begin{array}{l}\text { Variety of } \\
\text { historical and cultural } \\
\text { heritage monuments }\end{array}$ & \begin{tabular}{l}
\multicolumn{2}{c}{ Lack of distribution } \\
channels of tourist \\
products outside of \\
Russia
\end{tabular} \\
\hline $\begin{array}{l}\text { Unique } \\
\text { architecture in the } \\
\text { style of "Art } \\
\text { Nouveau", classicism } \\
\text { and rational } \\
\text { modernist }\end{array}$ & $\begin{array}{l}\text { Insufficient } \\
\text { systematization of offers } \\
\text { on the market }\end{array}$ \\
\hline $\begin{array}{l}\text { Cities of rocket } \\
\text { builders }\end{array}$ & $\begin{array}{l}\quad \text { Lack of a mobile } \\
\text { application with } \\
\text { information for tourists }\end{array}$ \\
\hline $\begin{array}{l}\text { Possibility of } \\
\text { expanding seasonal } \\
\text { offers and the absence } \\
\text { of a "dead season" for } \\
\text { tourists }\end{array}$ & $\begin{array}{l}\text { Lack of signs in } \\
\text { foreign languages on the } \\
\text { proposed tourist routes }\end{array}$ \\
\hline
\end{tabular}

Source: compiled by the authors.

In terms of improving the tourist attraction of the city, Samara and Saratov need to use their strengths. So, the Volga river is one of the most popular river names in Russia and abroad, so you should use the recognizability of this river. The strengths of Samara and Saratov are their historical and cultural heritage, including the Soviet era. Here, in our opinion, we should emphasize the mysterious halo of "closed" cities, which were industrial bases for the Soviet space program and the development of the defense industry. However, it is necessary to take into account the weaknesses of the analyzed cities. Currently, there is a need to strengthen interaction with travel companies, train local tourist operators and managers to work with foreign tourists, improve the quality of service and hotel services for tourists, develop new sightseeing tours and tourist routes, present Samara, Saratov at the main tourist exhibitions, where specialists could present their cities and show their unique features.

The authors consider the existing opportunities and obstacles for the development of cities and realization of their economic potentials (Table 2).
Tab. 2. Opportunities and obstacles for the development

\begin{tabular}{|c|c|}
\hline Opportunities & Obstacles \\
\hline $\begin{array}{l}\text { Search for new } \\
\text { "undiscovered" } \\
\text { excursion destinations } \\
\text { for tourism }\end{array}$ & $\begin{array}{l}\text { Lack of information } \\
\text { resources }\end{array}$ \\
\hline $\begin{array}{l}\text { Interest in travel } \\
\text { related to space }\end{array}$ & $\begin{array}{l}\text { Lack of a single } \\
\text { portal in Russian and } \\
\text { foreign languages }\end{array}$ \\
\hline $\begin{array}{l}\text { Increased use of } \\
\text { new media } \\
\text { technologies, such as } \\
\text { information retrieval, } \\
\text { hotel reservation, and } \\
\text { sales channels }\end{array}$ & \begin{tabular}{lrr}
\multicolumn{2}{c}{ Weak interaction } \\
with foreign & tour \\
operators and MICE \\
agencies
\end{tabular} \\
\hline $\begin{array}{cc}\text { Growth } & \text { of } \\
\text { specialized tours }\end{array}$ & $\begin{array}{l}\text { Low motivation of } \\
\text { travel companies in } \\
\text { Samara, Saratov }\end{array}$ \\
\hline $\begin{array}{c}\text { World Cup in } \\
\text { Samara in } 2018\end{array}$ & $\begin{array}{l}\text { Ramshackle } \\
\text { historical buildings and } \\
\text { architecture monuments }\end{array}$ \\
\hline
\end{tabular}

Source: compiled by the authors

It is necessary to increase the potential for the development of tourism in city marketing, which should become an important branch of the economy. Tourism promotes the popularization of historical and cultural monuments, strengthens the high authority of the city in the country and abroad, and is able to improve the quality of life of its population. Revenues from tourism activities can represent significant resources for maintaining and preserving the city's historical and cultural heritage. It is necessary to develop a model of cultural tourism in each specific city, based on taking advantage of the city's historical and cultural heritage for the development of tourism, which should be aimed at the revival of forgotten traditions and art forms, the creation of new tourist interest centers, and the organization of special types of routes. Tourist and excursion work should use the full potential of the city's cultural heritage, ensuring a uniform seasonal distribution of tourist flows, as well as creating comfortable conditions for accommodation and movement of guests and residents of the city. The tourism industry should be actively involved in the development of cities and the realization of their potentials. 
At the same time, it is necessary to establish a publicprivate partnership with representatives of tourism companies, business structures and municipal authorities on mutually beneficial terms. As an example, we can cite the redesign project of the historical center in Kazan, implemented by the investment group of ASG companies. Thanks to public-private partnership, the infrastructure for international and domestic tourism has been created, the social and cultural background of the city is being improved. Cultural-cognitive tourism, which is realized within the framework of public-private partnership, can become an important means for developing the potential of historical and cultural heritage and ensuring the preservation of cultural objects.

The development of combined tours will increase the attractiveness of routes, the projects of international importance, the exchange of museum sites, the creation of routes of interregional significance that unite similar resources (for example, the legacy of Leo Tolstoy, V. I. Lenin, M. Gorky, aviation subjects). The administration of Samara, Saratov should establish cooperation with neighboring regions to create combined tours and programs. For example, the "Golden Ring of Russia" or create a program called "Kazan-Samara-Saratov".

In connection with the holding of the World Cup in Samara in 2018, there is an enormous opportunity to present and show it to the world community as a city of unique architecture, art and culture. Many cities in the world used the opportunity to conduct major social events to attract a large flow of tourists and investors to their cities, and after these events they became known and interesting.

Today, the individual and society need obtain information, in general, and in particular about historical and cultural heritage of cities, since this necessity has greatly increased, modern information technologies, of course, play a fundamental role in obtaining and transferring knowledge. The main goal of modern information technologies is to provide complete and reliable information about historical and cultural heritage objects. The application of simultaneous sound, visual and graphic information has a great effect and a significant emotional charge. Creation of a graphic, visually beautiful and constantly functioning city site is an indispensable element for the development of its tourism industry, since the promotion of tourism products and services via the Internet is particularly important.

Thus, the preservation and maintenance of historical and cultural heritage should be a key element of the city's marketing strategy. The task of preserving cultural heritage should be decided not only by the monuments protection agencies, but also by structures that deal with urban planning and architecture, economics and industrial development, ecology, transport, improvement, property complex, housing and communal services, and jurisprudence. At the same time, the basic principle is the complex preservation of historical and cultural heritage, according to which this activity is effective only within the framework of the city's economic and social development policy, as part of long-term planning and urban planning projects.

\section{Stages of Implementation}

The development of city marketing, using its historical and cultural heritage, needs a phased implementation. At the first stage, the current situation and the state of the urban environment are analyzed. At the second stage, the marketing strategy is formed and the rationale for the development of the city's economic potential is established. The third stage is the establishment of processes, their coordinated interconnection and interaction, identification of key processes necessary to achieve the set goals for economic development and enhance the city's potential. At the fourth stage, the necessary organizational and methodological documentation is being developed to implement the marketing strategy. At the fifth stage, the plan and the program for carrying out activities to implement the marketing strategy are compiled and followed up. At the sixth stage, the effectiveness of the measures taken to implement the marketing strategy and finalize the existing documentation is evaluated. The final stage is the continuous improvement of the city's marketing activity and the further growth of its economic potential.

\section{Discussion}

The analysis results of the urban environment in Samara, Saratov show that in many regions, culture is not the first question in discussing the prospects of urban development, which is also rightly noted by the famous British researcher C. Landry (2000) [19]. At the present time, the problems of long-term planning, the development of town planning plans, economic issues, etc. take center stage. Issues of culture and preservation of historical and cultural heritage in such cases are practically not discussed. In order to attract attention of official representatives of municipalities to the issue of culture, who are responsible for making decisions on the development of their territories, the representatives of culture need to take a number of steps. One of them is a revision of historical and cultural resources, which make the city unique, the definition of cultural differences and the identification of so-called cultural exotics. 
In the 1980-90s., research and revival of individual cultural objects, that are valuable to local communities, has become an independent industry to create attractions, aimed at attracting tourists. Researchers Green M. and G. Richards (Green \& Richards, 2001) [20] called this process, based on the re-interpretation of the environment, the phenomenon of "heritagization of space" ("heritagization of space"). This industry now has a well-developed methodological basis in the form of the theory of "commodification" ("comradisation") of heritage, most fully expressed by G. Ashworth (1994) [21]. This approach, which explains the process of transformation of a physical cultural or historical resource into a product through the theory of marketing, continues to be one of the most effective and significant fundamental foundations of modern heritage management (cultural resources).

The most important role in "commodification" is played by the process of interpretation, which includes three stages which are typical for the usual product: selection of raw materials, manufacturing ("packaging") and its subsequent promotion. The founder of the theory "interpretation of cultural heritage" - Freeman Tilden (2008) [22] - identified the main purpose of this process, which is to reveal the meaning of the historical and cultural heritage object, and to establish contacts between the object and the visitor. This process allows us to come to a new understanding based not only on knowledge, but also on spiritual and emotional experience. Knowledge is, first of all, information, facts and history about the object, as well as the expected parameters for different audiences - social groups of consumers, and the assessment and understanding of available resources is conducted.

In practice, the methodologists of the US National Parks Service (SNP) characterize the concept of "interpretation" as a procedure for finding a topic that will be effective for contacting cultural heritage of different social groups. In the US, the SNP is guided by a simple interpretation formula:

$(\mathrm{KR}+\mathrm{KA}) / \mathrm{AP}=\mathrm{PI},(1)$

where KR - knowledge of resources;

KA - knowledge of the audience;

AM - appropriate methods;

PI - possibility of interpretation.

The interpretation approach is based on the attitude expressed in increased attention to consumer needs and their consideration in creating a cultural product (that is the classic for marketing), and allows establishing a communication channel between the values of the past and the present. The main task is not the demonstration of individual masterpieces, but the creation of the integral convincing atmosphere, a variety of techniques and means are used to go into it. It is appropriate to believe that "in reality, the subjects of trade are not physical components of heritage, such as historical monuments and objects, but intangible ideas and sensations such as fantasy, nostalgia, pleasure, pride transmitted through the interpretation of physical elements" (Tunbridge \& Ashworth, 1996) [23]. Historical and cultural heritage reveals different stories, and it is important for the visitor to find his own one, which will interest him and draw his attention. In our opinion, it is necessary to emphasize the special attention on it, determining perspective directions of the city marketing development and attracting tourists to visit this city. If we consider popularization of historical and cultural heritage, it differs from the interpretation activity by the fact that popularization is based directly on the fact that history is a value for a person and it is a need.

Unfortunately, in modern Russia, the interpretation approach has not been widely disseminated at the level of its regions yet. Nevertheless, there are many positive examples in this respect. It should also be noted that in Russia the awareness and use of historical and cultural heritage as a symbolic capital of the city is not so popular in cultural capitals (where, as a rule, historical monuments are wrecking), as in provincial cities (including in the cities of Samara, Saratov, Tambov, Tula, etc.).

Specialists, who are rethinking of the past, creating interesting cultural stories from it, work in the Association of Cultural Managers, the Creative Industries Agency, the Creative Industries and Cultural Tourism Development Foundation and other organizations. At present, wide support in the expert community, as well as in the mass media, has been received: the All-Russian competition of projects "The Changing Museum in the Changing World", supported by Vladimir Potanin Charitable Foundation; Open competition of cultural projects "Cultural Capital of the Volga Region"; competitions of socio-cultural projects "Culture. Tourism. Information" (Karelia) and the Fair of Socio-Cultural Projects in the Samara Region, implemented at the regional level.

The study called "Samara: Endangered Heritage on the Volga", "Samara architects and art historians in cooperation with the Moscow Society for the Protection of Architectural Heritage and Save Europe's Heritage" analyzed historical and cultural heritage in detail. This study included the analysis of the current state of historical and cultural heritage objects in Samara. As a result of the study, it was concluded that Samara has a fantastic and unique historical and cultural heritage in Art Nouveau style, which, of course, should become part of the city style, in case if it is restored accordingly.

Thus, historical and cultural heritage can be used as an 
effective marketing tool for the creation and development of modern business, the city, both in the cultural sphere and outside it. As practice shows, business can use historical and cultural heritage in at least three directions: first, when creating or strengthening a company's brand; secondly, with the release of certain goods and services in the retro style, and, thirdly, in individual advertising and PR-actions that use heritage and traditions of past eras.

\section{Conclusion}

Studying historical and cultural heritage of the city and its accounting in the process of further improving the city's marketing activity are indispensable attributes for the development and subsequent transformation into innovations. Changing views, some aspects disappear, while others, on the contrary, are renewed and modified, others are subject to further transformation and new ones are emerging. Once emerged, they will, as a rule, not disappear, but will appear when the time comes. Change, transformation of cultural meanings in the process of mastering historical and cultural heritage is inevitable. At the same time, one of renewal sources is the past, which "comes to life" in the present.

The examples and results of the analysis on using historical and cultural heritage in city marketing in the Volga Federal District of the Russian Federation (using the example of Samara, Saratov) allow concluding that, in modern conditions, the processes of actualization and commercialization of historical and cultural heritage have already been comprehended at the theoretical and methodological level and have been implemented in the practical activities of cultural institutions and business companies, but they are used inadequately for the development and improvement of the city and the quality of life of its inhabitants. Integration of modern architecture and historical buildings should be carried out with special attention and create a unified style of the city. The new architecture in the context of the historical environment is one of the most important strategic components on preserving historical and cultural heritage. Zones of building regulation should determine the possibilities of new construction in the areas of the urban environment development. It is necessary to pursue a comprehensive active policy on preservation of historical and cultural heritage as an integral part of all aspects of urban planning and economic development of city marketing. The materials of the article are of great importance for official representatives of municipalities, regional authorities when developing the marketing strategy of the city, as well as when developing measures aimed at improving the efficiency of the management system of municipalities. Decisions made by the regional authorities in the areas of construction and improvement should be made taking into account the need to preserve historical and cultural heritage of the city.

\section{Acknowledgement}

The authors express gratitude to the official representatives of municipalities in the cities of Samara, Saratov for providing information on historical and cultural heritage objects located in these territories!

\section{References}

[1] Galkin, D.V. (2005). Strategies of cultural development of cities: modern approaches. Journal of Sociology and Social Anthropology, Vol. 4, pp. 41-57.

[2] Delafons, J. (1997). Politics and Preservation: A Policy of the Built Heritage.

[3] Morris, U. (1973). Art and life. Moscow: Art, p. 512.

[4] Rypkema, D.D. (2005). Cultural Heritage and Sustainable Economie and Social Development. European Cultural Heritage Forum. Brussels: Belgium.

[5] Highfield, D. (1991). The Construction of New Buildings Behind Historic Facades. CRC Press, $155 \mathrm{p}$.

[6] Harvey, D.C. (2001). Heritage Pasts and Heritage Presents: temporality, meaning and the scope of heritage studies. International Journal of Heritage Studies, Vol.7, 319-320.

[7] Doyl', P. (2001). Cost-oriented marketing. St. Petersburg: Piter, $480 \mathrm{p}$.

[8] Drucker, P. (2007). Managing in the Next Society. Moscow: Vil'yams, $320 \mathrm{p}$.

[9] Kotler, F., Dzhayn, D.K., \& Meysinsi, S. (2003). Maneuvers of marketing. Modern approaches to profit, growth and renewal. Moscow: Olimp-Biznes, 224 p.

[10]Porter, M.E., \& Kramer, M.R. (2006). Strategy and Society: The Link Between Competitive Advantage and Corporate Social Responsibility. Harvard Business Review, 78-92 pp.

[11] Abankina, T.V. (2003). Social marketing: approaches and strategies. 60 parallel, 1(8), pp. 15.

[12] Ignat'yeva, Ye.L. (2013). The economy of culture. Moscow: GITIS, p. 383. 
[13] Kostina, Ye.P. (2012). Culture of Russia. The 2000's. Moscow: State Institute of Art Studies, p. 865.

[14] Muzychuk, V.Yu. (2013). State support of culture: resources, mechanisms, institutions. Moscow, Saint Petersburg: Nestor-Istoriya, p. 280.

[15] Rubinshtein, A.Ya. (2013). Actual problems of the economy of cultural heritage, $108 \mathrm{p}$.

[16] Rudnik, B.L. (2015). Transformation of economic mechanisms in the sphere of culture: consistent development or movement in a circle? Issues of state and municipal management, Vol.3, pp. 83-102.

[17] Yakobson, L.I., \& Rudnik B.L. (2015). Economic aspects of cultural policy in postSoviet Russia. Social sciences and modernity, 5, pp. 35-47.

[18] Decree of the Government of the Saratov region "On the Strategy for the Development of the Cultural Heritage of the Saratov Region" (23.05.2008). 213-P (as of January 2016).

[19] Landri, C.H. (2000). Development of cities through culture. Ecology of culture, 6(19), pp. 11-12.

[20] Green, M., \& Richards, G. (ed.). (2001). Urban Heritage Tourism: Globalization and Localization. Cultural Attractions and European Tourism. CABI Publishing, 181.

[21] Ashworth, G.J. (1994). From history to heritage - from heritage to identity. In search of concepts and models. In: G.J.Ashworth and P.J.Larkham (eds). Building a New Heritage. Tourism, Culture and Identity in the New Europe. London: Routledge.

[22] Tilden, F. (2008). Interpreting Our Heritage, $210 \mathrm{p}$.

[23] Tunbridge, J.E., \& Ashworth, G.J. (1996). Dissonant Heritage: The Management of the Past as a Resource in Conflict. Brisbane: John Wiley and Sons, p. 8. 